\title{
Becoming a Middle Class Pentecostal: Biographies, Backgrounds, and Beliefs
}

When Fabian, a young bank employee from an upper-middle class background, converts to Pentecostalism, he starts to face pressure from various sides: he loses his old friends and the material support-cars, housing, and money - from his father who regards Pentecostal pastors as swindlers dedicated to the exploitation of their members. Moreover, his colleagues at work laugh at his new Pentecostal identity and begin to harass him. He states that he feels in these situations often like the evangelical character Ned Flanders from the famous cartoon series The Simpsons. ${ }^{1}$

As in the case of Fabian, many of the middle class Pentecostals that I interviewed experienced some type of tension related to their Pentecostal identity. They were expelled from their secular peer-group, suffered conflicts with their parents or spouses, or were mocked at work and felt embarrassed for being a Pentecostal. These tensions illustrate that Pentecostalism is not well accepted among the middle class. Pentecostalism clashes to some degree with what is expected from the educated urban middle class. This raises the question how middle class individuals become Pentecostals. What factors drive them to walk through the entrance hall of a Pentecostal church and convert to such an "inappropriate" faith?

This chapter tackles this question by exploring 44 in-depth interviews with Pentecostals: 30 middle class Pentecostals and a control group of 14 lower class Pentecostals. With respect to the small sample of middle class Pentecostals, the chapter does not endeavor to offer a comprehensive explanation of middle class religious conversions. Instead, it attempts to provide some clues that may help to understand which factors facilitate the conversion of educated middle class Argentineans to Pentecostalism.

The chapter starts with a brief description of the religious practices and beliefs of the interviewees. It is followed by a section discussing their social class background and another section describing their religious backgrounds. The chapter ends with a reflection about the factors that contributed to middle class conversions to Pentecostalism.

1 Interview Fabian Part 1.

(C) JENS KOEHRSEN, 2016 | DOI 10.1163/9789004310148_007

This is an open access chapter distributed under the terms of the Creative Commons Attribution-

Noncommercial 3.o Unported (CC-BY-NC 3.0) License. 


\subsection{Religious Belief and Practice among Middle Class Interviewees}

Despite the "inappropriateness" of their faith, the middle class Pentecostals that I interviewed present themselves as firm believers and practitioners of Pentecostalism. They do not shy away from the potential stigma and deny their Pentecostal identity and beliefs. However, when communicating their faith to friends, relatives or colleagues they may face limits and sometimes even open discrimination.

All interviewees - lower and middle class interviewees - describe themselves as Pentecostal. They are affiliated with Pentecostal churches and attend services on a regular basis. Many interviewees even participate several times a week in different activities of their congregation such as church services, Bible groups, courses and workshops.

Concerning their beliefs, all interviewees share the basic Pentecostal belief in the experience of the Holy Spirit and reception of its gifts. Surprisingly, middle class interviewees show no significant differences in their religious beliefs from those of lower class interviewees. When I started my research, I supposed that educated middle class Pentecostals would tend to be more skeptical with regard to some Pentecostal beliefs. However, this is not the case. All interviewees share the similar pool of beliefs. First and foremost, they believe that the supernatural intervenes in daily life: supernatural interventions take place in the form of the Holy Spirit, curses, demonic possessions, faith healing, spiritual gifts, etc. Hence, in the mindset of my interviewees the supernatural and empirical spheres are deeply intertwined. Moreover, human beings are believed to be able to receive specific supernatural gifts, dones, which may, for instance, enable them to heal other individuals from lethal diseases. The belief in faith healing and exorcism as well as the blessings of the Holy Spirit and miracles is ubiquitous among the interviewees. They also believe that non-Christian religious actors are able to "manipulate" supernatural forces in order to alter empirical reality. In particular, Curanderos, Brujos and Afrobrazilian religions are regarded as potential suppliers of such spiritual services. Interviewees do not deny that these actors may relieve their clients from suffering, but rather describe them as receiving their spiritual power from satanic forces. Consequently, interviewees reject these types of religious practice as satanic and dangerous.

Middle class informants are not more secular in their beliefs than the lower class informants of the sample. There are no indicators that middle class Pentecostals believe less in the supernatural and its empirical manifestations in daily life than their lower class peers. Both middle and lower class interviewees share the same holistic worldview. Whilst the holistic worldview is generally 
described as a feature of popular religiosity which is attributed to the lower class, the sample group of this study includes highly educated middle class individuals who show a strong attachment to the holistic worldview. However, the expectation exists that the educated middle class is more secular and rational, and less "superstitious" than the lower class. Pentecostal beliefs in demons, divine miracles and the gifts of the Spirit do not represent the typical characteristics one would expect to find among the educated middle class of Buenos Aires. This raises the question of how they became Pentecostals. As will be discussed in the following sections, the belief in the concepts of popular religion and the conversion to Pentecostalism are closely interrelated. In particular, religious upbringing appears to play a crucial role.

\subsection{Social Positions and Class Backgrounds of Interviewees}

This section describes the "objective" social background and current status of the interviewees. This description delivers a general overview of the sample of interviewees on which this study is based. ${ }^{2}$ The insights into the social background of middle class interviewees will enable us at a later point to suggest an explanation for the conversion of middle class Pentecostals.

Figure 5 represents a social space displaying the interviewees' current social positions and some of their professions. This space combines the variables of household income per capita in Argentinean pesos and education in the form of education degrees. The red dots indicate the social positions of lower class interviewees and the blue circles the social positions of middle class interviewees. This space serves as an illustration of the "objective" class differences within the sample. Lower class interviewees are located at the lower left of the space, whereas middle class interviewees are situated at the upper right.

The majority of lower class informants work in unstable, informal work relations. Two of the interviewees are unemployed and live under uncertain circumstances working from time to time in casual employments. Other interviewees work as domestic employees, hair dressers, painters, cleaners, food sellers, and forklift truck drivers. All lower class informants have a formal education lower than completed secondary school: four left primary school before finishing, five finished primary school without having ever started secondary school, four started secondary school but dropped out before finishing and one was restarting her secondary school studies.

2 The same sample will be used in the eighth chapter to describe the taste of middle class Pentecostals. 


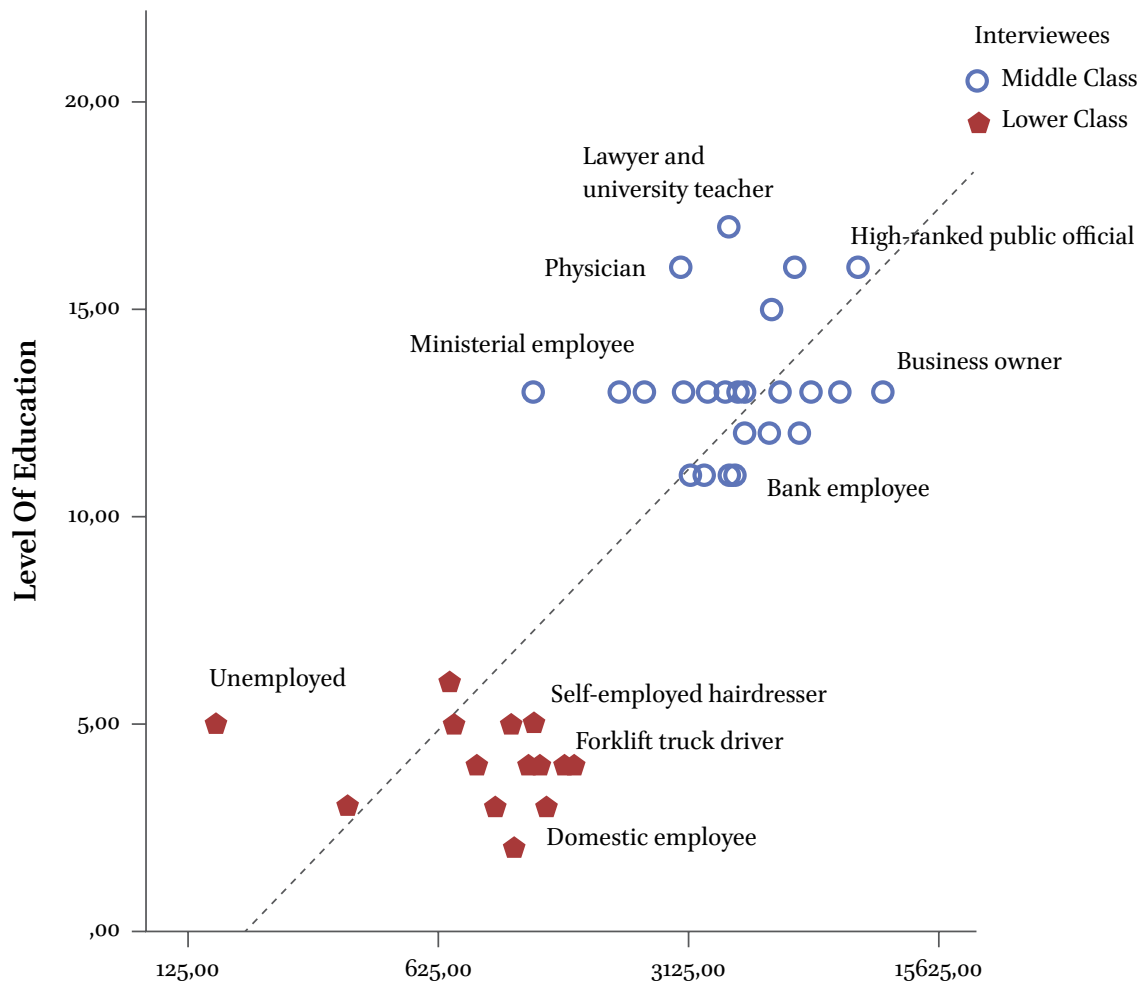

Household Income Per Capita

FIGURE 5 Social positions of interviewees ${ }^{3}$

(OWN SOURCE)

The most frequent job occupations in the middle class group are lawyers, physicians, architects, public officials, and business owners. ${ }^{4}$

The educational composition of the middle class interviewees is shown in table 1. The majority of interviewees in this group $(76.6 \%)$ holds a completed

3 This social space is constructed on the basis of data from the interview partners and is not representative of Argentinean society. The vertical axis which shows the education degrees of interviewees starts at illiteracy (o) and ends with a completed PhD degree (18). In order to integrate all informants into the space, the horizontal axis showing household income per capita was compressed with a logarithm of five. Consequently, the income per capita in the scale does not rise in a linear manner, but logarithmically. For interviews conducted during the second wave of interviews in 2011 the household income was multiplied by 0.75 to counterbalance the effect of rising incomes.

4 The economic situations of middle class informants vary significantly. The highest household income per capita was at 10825 Argentinean pesos per month almost ten times higher 
TABLE 1 Educational degrees of middle class interviewees (own source)

\begin{tabular}{lrr}
\hline & N & \multicolumn{1}{l}{$\%$} \\
\hline University student & 4 & 13.3 \\
Completed Terciario & 3 & 10.0 \\
Completed university & 18 & 60.0 \\
Postgraduate student & 1 & 3.3 \\
Completed postgraduate & 3 & 10.0 \\
PhD student & 1 & 3.3 \\
Total & 30 & 100.0 \\
\hline
\end{tabular}

university degree or higher. The lowest formal education level is "university student" while the highest is "PhD student".

In general terms, the middle class interviewees are part of the educated middle and upper middle class of Buenos Aires city. Besides their elevated cultural and economic capital, they share some other features: they are homeowners who frequently employ domestic servants, own at least one (in many cases brand new) car, and send their children to private schools.

Also with regard to the "objective" class backgrounds during childhood, there are some differences between the two groups. The social backgrounds of lower class interviewees are illustrated in table 2. The table shows the social position of the parental household during the individual's childhood: it combines the educational degrees of the parents - in this case the highest of the two degrees - and the economic position of interviewees during their childhood. ${ }^{5}$

The parental household of lower class interviewees can be described in the majority of cases as lower class. Seven of them grew up in poverty while five had a rather stable lower class background. In two cases, informants have a lower middle and middle class background. The main segment of lower class interviewees faced different hardships during their childhood such as economic

than the lowest at 1154 Argentinean pesos. Yet, the lowest income is an exception among the group of middle class interviewees and there are doubts with regard to the correctness of the income data of this informant. The majority of household incomes per capita range between 3000 and 7000 Argentinean pesos per month in the middle class group.

5 The economic class statuses were summarized for this table and the subsequent tables: the categories "absolute poverty (misery)" and "poverty" were combined as "poverty", "lower class" and "stable lower class" to "lower class", and "upper middle class" and "upper class" to "upper middle class". 
TABLE $2 \quad$ Social background of lower class interviewees during childhood (own source)

\section{Parents' education}

\begin{tabular}{|c|c|c|c|}
\hline $\begin{array}{l}\text { Incomplete } \\
\text { primary }\end{array}$ & $\begin{array}{l}\text { Completed } \\
\text { primary }\end{array}$ & $\begin{array}{l}\text { Completed } \\
\text { secondary }\end{array}$ & $\begin{array}{l}\text { Completed } \\
\text { higher } \\
\text { education }\end{array}$ \\
\hline
\end{tabular}

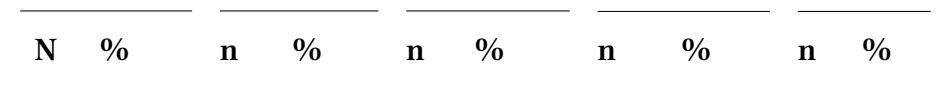

\begin{tabular}{|c|c|c|c|c|c|c|c|c|c|c|c|}
\hline Economic & Poverty & 3 & 21.4 & 4 & 28.6 & o & 0.0 & o & 0.0 & 7 & 50.0 \\
\hline \multirow[t]{7}{*}{ Upbringing } & Lower Class & o & 0.0 & 4 & 28.6 & o & 0.0 & o & 0.0 & 4 & 28.6 \\
\hline & Lower & o & 0.0 & 1 & $7 \cdot 1$ & o & 0.0 & o & 0.0 & 1 & 7.1 \\
\hline & Middle Class & & & & & & & & & & \\
\hline & Middle Class & o & 0.0 & o & 0.0 & 1 & 7.1 & 0 & 0.0 & 1 & 7.1 \\
\hline & Upper & o & 0.0 & 1 & 7.1 & o & 0.0 & 0 & 0.0 & 1 & 7.1 \\
\hline & Middle Class & & & & & & & & & & \\
\hline & Total & 3 & 21.4 & 10 & 71.4 & 1 & 7.1 & $O$ & 0.0 & 14 & 100.0 \\
\hline
\end{tabular}

deprivation, hunger, domestic violence, psychological and/or sexual abuse. In many cases, they migrated as teenagers or adolescents from rural areas or small towns to the urban area of Buenos Aires where they expected to have a better future. For some of my interviewees this hope became true, particularly for those who grew up in misery. They experienced an absolute improvement in their life: hunger or other types of serious material deprivation disappeared from their daily reality. In relative terms, however, they are located close to - or even at - the end of the social hierarchy. ${ }^{6}$

The "objective" class backgrounds of the middle class informants are more mixed with a majority of interviewees coming from the middle class. Some of the middle class informants were raised in an upper middle or even upper class environment. Table 3 displays the "objective" social positions of the parental homes of middle class interviewees. ${ }^{7}$

6 Yet, not all lower class interviewees experienced social improvement: two interviewees who came from middle class backgrounds suffered social decline. Their loss of social status appears to be partly a product of dysfunctional family backgrounds.

7 The table shows that seven of the middle class interviewees grew up in a home where the economic situation was lower class or lower middle class and the parents held less than a 


\section{Parents' education}

\begin{tabular}{|c|c|c|c|c|}
\hline $\begin{array}{l}\text { Incomplete } \\
\text { primary }\end{array}$ & $\begin{array}{l}\text { Completed } \\
\text { primary }\end{array}$ & $\begin{array}{l}\text { Completed } \\
\text { secondary }\end{array}$ & $\begin{array}{l}\text { Completed } \\
\text { higher } \\
\text { education }\end{array}$ & Total \\
\hline$\%$ & $\%$ & $\%$ & $\%$ & $\mathbf{n}$ \\
\hline
\end{tabular}

\begin{tabular}{llrrrrrrrrrr}
\hline Economic & Poverty & 0 & 0.0 & 0 & 0.0 & 0 & 0.0 & 0 & 0.0 & 0 & 0.0 \\
Upbringing & Lower Class & 1 & 3.3 & 4 & 13.3 & 3 & 10.0 & 0 & 0.0 & 8 & 26.7 \\
& Lower & 1 & 3.3 & 1 & 3.3 & 1 & 3.3 & 0 & 0.0 & 3 & 10.0 \\
& Middle Class & & & & & & & & & & \\
& Middle Class & 1 & 3.3 & 1 & 3.3 & 3 & 10.0 & 1 & 3.3 & 6 & 20.0 \\
& Upper & 0 & 0.0 & 2 & 6.7 & 8 & 26.7 & 3 & 10.0 & 13 & 43.3 \\
& Middle Class & & & & & & & & & & \\
Total & 3 & 10.0 & 8 & 26.7 & 15 & 50.0 & 4 & 13.4 & 30 & 100.0
\end{tabular}

None of the middle class informants grew up in poverty or misery and only a small group among them had a clear lower class background. This picture was also confirmed in the narratives about their childhood: unlike lower class informants, most middle class informants stated that they experienced a happy and carefree childhood without any type of deprivation or abuse. Instead, their parents and grand-parents were the ones who had suffered economic hardships. All middle class interviewees are descendants of European immigrants, most of them from an Italian or Spanish background. Many told me that their grandparents had migrated from Europe to Argentina in order to

secondary school degree. These cases can be described as lower class backgrounds. Seven other cases are located on the border between lower and middle class: in four cases the parents held school degrees lower than secondary school but the household is economically integrated in the middle class, and in three other cases one of the parents had at least a secondary school degree but the economic situation of the parental household was lower class. The remaining sixteen cases - which form $53.3 \%$ of my middle class interviewees - have a middle class background with one of the parents holding at least a secondary school degree and an economic situation of at least lower middle class. Among this group are eleven interviewees that were even raised in upper middle class households. 
escape poverty. Newly-arrived in Argentina, they started as unskilled workers and lived under poor material conditions, but managed to gradually improve their situation through hard work. Due to these improvements they were able to provide their children an economically more stable background and access to education. Aspiring to upward social mobility, the parents of my interview partners enhanced their "objective" social position through educational training. They became skilled workers, white collar employees or even opened their own businesses. Many among them finally achieved middle class status. Thus, in most cases, the parental household of my middle class informants was already marked by upward social mobility. Similar to their parents, interviewees strive for further improvements. Many experienced an improvement, whereas in other cases they maintained their social position. ${ }^{8}$

The preferred strategy for realizing social enhancement was education and hard work: many middle class informants stressed the hard work and sacrifices they made in order to finish their studies and reach their current social position. Particularly important was education. Middle class informants usually reached higher levels of education than their parents. While at least one of their parents generally held a secondary school degree, most of the middle class interviewees had achieved a higher education degree. Moreover, many middle class informants continued to study in some educational program after having finished their higher education degree. Several interviewees, for instance, frequented Bible institutes or some type of postgraduate program. Middle class informants tended to stress the importance of education, personal development, and progress ideals which fit well to the representations of the Argentinean middle class. ${ }^{9}$

The fact that most middle class interviewees have a middle class background and have therefore grown up in a social environment which was framed by the

8 In particular, interviewees with lower and lower middle class backgrounds enhanced their social position, while those with middle class backgrounds maintained or slightly improved their position. Only in two cases there appears to have occurred a slight social decline since the economic background of the two individuals was potentially upper class. From the 1980 on onwards, the Argentinean middle class has experienced a partial fragmentation process which is believed to have caused a dichotomization into economic winners and losers. Although there are significant differences in the incomes of the middle class sample including some interviewees who may have benefited from the social transformations and others that were negatively affected - the vast majority of the interviewees belong neither to the winners nor the losers of the social transformation. By contrast, most of the informants make up part of a relatively stable middle class. Moreover, all middle class interviewees from the sample had a positive perception of their future and believed that they would experience further economic improvements within the following five to ten years. 
representations of the middle class will help us to form an explanation for their conversion to Pentecostalism in the following sections.

\subsection{Religious Backgrounds and Trajectories}

The following paragraphs explore the religious biographies of the interviewees and deal with the question of what factors made the middle class interviewees susceptible to becoming Pentecostal. ${ }^{10}$ The emphasis is on the middle class interviewees. Their religious upbringing will be discussed together with the trajectories that drove them to become Pentecostals. One can distinguish between five types of religious upbringing: popular Catholicism, orthodox Catholicism, non-active (or nominal) Catholicism, evangelical Protestantism, and a mixed (evangelical and catholic) upbringing.

Table 4 displays the religious upbringing of lower and middle class informants. Religious upbringing is defined here as the religious practice in which the given actor is involved during his/her childhood. Although the religious practice of most actors is shaped by that of their parents, in a few cases informants practiced a religion different from that of their parents. Sara, for instance, grew up with Catholic parents who sent her to Catholic Church. But at the same time she participated in a Pentecostal church to which she was more committed than to the Catholic Church. Consequently, her upbringing is defined in the table above as evangelical and Catholic.

The religious biographies of lower and middle class interviewees show some differences: most lower class respondents grew up in an environment of popular Catholicism while the sample of middle class respondents exhibits a greater variety. Notably, many of the middle class interviewees had early contact with evangelical Protestantism.

\subsubsection{The Religious Biographies of Lower Class Interviewees}

The religious upbringing of the majority of lower class informants is shaped by popular Catholicism. Eight of the fourteen lower class informants grew up in a religious environment of popular Catholicism. Rather than by regular participation in

10 The religious conversion studies of the informants will however not be the focus of this study. This is due to two reasons. First, religious conversion is not the topic of this research. Second, Pentecostal conversion is an extensively studied topic (cf. Gooren 2005; 2007; 2010a; Steigenga and Cleary 2007). There exist already a vast number of studies about conversion to Pentecostalism. Therefore, the conversion careers of the interviewees are only briefly addressed. 
Religious upbringing of lower and middle class interviewees (own source)

\begin{tabular}{|c|c|c|c|c|c|c|c|c|c|c|c|c|}
\hline & \multicolumn{2}{|c|}{$\begin{array}{l}\text { Popular } \\
\text { catholicism }\end{array}$} & \multicolumn{2}{|c|}{$\begin{array}{l}\text { Orthodox } \\
\text { catholicism }\end{array}$} & \multicolumn{2}{|c|}{$\begin{array}{l}\text { Catholicism, } \\
\text { not active }\end{array}$} & \multicolumn{2}{|c|}{$\begin{array}{l}\text { Evangelical } \\
\text { and catholic }\end{array}$} & \multicolumn{2}{|c|}{ Evangelical } & \multicolumn{2}{|l|}{ Total } \\
\hline & Count & $\begin{array}{l}\text { Row } \\
\text { N\% }\end{array}$ & Count & $\begin{array}{l}\text { Row } \\
\text { N\% }\end{array}$ & Count & $\begin{array}{l}\text { Row } \\
\text { N\% }\end{array}$ & Count & $\begin{array}{l}\text { Row } \\
\text { N\% }\end{array}$ & Count & $\begin{array}{l}\text { Row } \\
\text { N\% }\end{array}$ & Count & $\begin{array}{l}\text { Row } \\
\text { N\% }\end{array}$ \\
\hline $\begin{array}{l}\text { Lower } \\
\text { Class }\end{array}$ & 8 & 57.1 & o & 0.0 & 1 & $7 \cdot 1$ & 3 & 21.4 & 2 & $14 \cdot 3$ & 14 & 100.0 \\
\hline $\begin{array}{l}\text { Middle } \\
\text { Class }\end{array}$ & 7 & $23 \cdot 3$ & 5 & 16.7 & 6 & 20.0 & 2 & 6.7 & 10 & $33 \cdot 3$ & 30 & 100.0 \\
\hline Total & 15 & 34.1 & 5 & 11.4 & 7 & 15.9 & 5 & 11.4 & 12 & $27 \cdot 3$ & 44 & 100.0 \\
\hline
\end{tabular}

Sunday mass, their religious practice was characterized by the devotion to Catholic saints and the Virgin. In addition to the devotion to saints and virgins, they often accompanied their parents to witches or faith healers.

The case of Carolina exemplifies how some lower class individuals become familiarized early in life with popular religiosity. Carolina grew up together with 15 siblings on a farm in a rural area of Paraguay. Her parents did not frequent the Catholic Church but instead had numerous figures and images of virgins and saints in their house. Her mother even installed small cots with candles for the saints on the street. Moreover, Carolina was frequently sent with her siblings to a faith healer in order to perform faith healing practices with fabric belonging to her ill mother. The faith healer received food in exchange for his services. ${ }^{11}$

Three lower class interviewees were raised in a mixed environment of popular Catholicism and Pentecostalism. Besides experiencing popular Catholicism, they also had an intense relationship to Pentecostalism during their upbringing. Andrés, for instance, was brought up in a family in which the father practiced popular Catholicism while the mother tried out numerous non-Catholic religious options and finally ended up in a Pentecostal church. Due to the influence of his mother, he learned early about the Pentecostal faith.

11 Interview Carolina Part 3. 
The majority of lower class interviewees grew up in an environment of popular Catholicism: saints, the Virgin, witches, and faith healers shaped their religious universe. They were born as Catholics and converted from Catholicism to Pentecostalism. From their conversion onwards most of them disaffiliated and affiliated with different Pentecostal churches.

\subsubsection{The Religious Biographies of Middle Class Interviewees}

The religious biographies of the middle class interviewees are different from those of the lower class. Popular Catholicism is less prevalent. Many middle class informants had from early on some contact with evangelical Protestantism. In the following, I discuss each type of religious upbringing separately.

\subsubsection{Middle Class Pentecostals with Evangelical and Mixed Backgrounds}

In ten cases, middle class informants grew up in an evangelical household and were involved from early on in the practice of Protestantism. This group forms with $33.3 \%$ of middle class interviewees - the biggest group within the middle class. Their families were affiliated with evangelical congregations and practiced their faith on a regular basis. In addition, there are two cases in which interviewees practiced evangelical Protestantism and Catholicism during their childhood.

Remarkably, most interviewees in this group have a middle class background..$^{12}$ Hence, the majority of individuals in this group were already raised in families that deviated from the representations of the middle class and the general picture of lower class Protestantism. Among this group are many interviewees whose families have a long standing evangelical tradition.

Moreover, the majority of the interviewees in this group are born into a family with a Pentecostal tendency..$^{13}$ One example is Eduardo. He grew up in a Pentecostal household and was familiarized early with the Pentecostal faith. His upbringing was deeply shaped by the continuous practice of Pentecostalism. The family of his father has a long Protestant history.14

12 Only in three cases, interviewees with an evangelical background come from a lower class background. In two cases, parents of the interviewees hold even higher education degrees and in five cases they come from upper middle class or even upper class backgrounds.

13 Only in one case was an interviewee raised in a non-charismatic evangelical church: Andrea went with her parents to a traditional church of the Plymouth Brethren and switched later in her life with her husband to a Pentecostal church. In the remaining eleven cases interviewees participated from early on in Pentecostal churches. 
Different from the pure Protestant upbringing is the mixed religious upbringing in Catholicism and Protestantism. Two middle class informants practiced Catholicism and Protestantism during childhood. I have already mentioned the case of Sara who despite growing up in a Catholic household joined a Pentecostal church and was forced at the same time to participate in the religious activities of the Catholic Church. The other case is Emilia. Her Catholic mother frequently took her to Catholic mass on Sunday mornings, while Sunday evenings she attended with her Protestant grandmother a Pentecostal congregation. Thus, Emilia participated almost every Sunday in a Catholic and a Pentecostal church service. Moreover, she visited a Catholic private school. ${ }^{15}$

Individuals with an evangelical background were raised in at least a partly evangelical environment and participated on a regular basis in evangelical church services. At some moment during their youth - generally between 15 and 20 years of age - interviewees decided to stay in the movement and were baptized. They became Pentecostal. In some cases they had previously experienced a type of conversion process, in other cases it was just a change of status within the community. At some point in their life after their conversion they switched their congregational affiliation. All informants switched their church at least once, in some cases even several times.

The religious conversion to Pentecostalism in this group raises few questions. Those who grew up in a Pentecostal environment are also the most likely to join the movement and become Pentecostal. However, with respect to the middle class Pentecostals who have not experienced an evangelical upbringing, the conversion to Pentecostalism is less evident.

Besides the twelve cases that were mentioned here so far, there are also other interviewees who experienced an evangelical influence during their childhood but have not been attributed to the "evangelical group". They participated from time to time in the church services of evangelical congregations during their childhood. ${ }^{16}$

\footnotetext{
15 Interview Emilia.

16 Despite having a close relative who was Protestant, these interviewees did not practice Protestantism on a regular basis. I attributed the cases to other categories due to the absence of a regular practice of evangelical Protestantism. Two examples are Luis and Fabian. While their mothers were active Pentecostals, the official religion of Luis and Fabian was Catholicism. Nevertheless, both of them practiced neither Protestantism nor Catholicism during their childhoods. Therefore, they are defined as non-active Catholics.
} 
6.3.2.2 Middle Class Pentecostals with Religious Backgrounds in Popular Catholicism

Besides Protestantism, Catholicism in its manifold manifestations was in various cases an important factor during childhood. In seven cases, middle class interviewees grew up in a popular Catholic environment. They form the second largest group among the middle class interviewees.

Popular Catholicism consists of a variety of practices: petitions and promises to the saints and the Virgin, the consultation of faith healers, the use of wristbands for spiritual protection, etc. Alberto, for instance, reports that he made promises to the saints, went to the faith healer, and used different types of wristbands as a spiritual protection against envy. Moreover, the parental household of those who grew up in popular Catholicism were often marked by the presence of images of the Virgin and saints. Further, their parents took them on pilgrimages to saints and the Virgen de Lujan.

Popular Catholicism constitutes part of the religious universe of popular religion. It is based on a holistic world-view which supposes that supernatural beings influence the empirical life of individuals. The universe of popular religiosity and Pentecostalism are closely interrelated. Therefore, those who grew up in popular Catholicism are likely to also have an affinity for other types of popular religion such as Pentecostalism.

Sharing a similar worldview and similar practices, Argentineans who grew up in popular Catholicism may find appeal in Pentecostalism particularly when they face problems. In fact, the middle class interviewees from this group converted to Pentecostalism when they faced a crisis in their life. Most of them became Pentecostals in the course of a depression or life crisis. At the same time, they had a friend or relative who was already involved in the movement and facilitated their first contact with a Pentecostal church. One example is the case of Pedro who suffered from panic attacks. He was afraid to die and leave his family alone. His wife who had recently become a member of a Pentecostal church invited him to visit the consultation program of the church. After participating in the initial consultations, Pedro started visiting the church services and finally converted to Pentecostalism.

\subsubsection{Middle Class Pentecostals with Non-Active Catholic Backgrounds} Another widespread form of Catholicism consists of a nominal, non-active Catholicism. In six cases, middle class interviewees reported to me that they were raised in Catholic families but abstained from any type of regular religious practice. They were baptized as Catholics, but practiced Catholicism neither in a popular nor in an orthodox fashion. 
Only in one case was an interviewee dedicated to a regular religious practice during childhood: Mateo and his family were officially Catholic, but practiced a form of spiritism in the escuela espiritista. He describes the practices of this group as quite similar to those of Pentecostalism. Later he experienced his first contact with Pentecostalism due to a relative, but did not convert immediately to Pentecostalism. In the context of a crisis in his business career, he started visiting a Pentecostal church and finally converted to the movement.

In the remaining five cases in this group, interviewees did not practice any type of religion on a regular basis during their childhood. Although some of their parents were believers and even practicers of a religion, the interviewees stayed away from any type of active religious affiliation. Nevertheless, four of them visited from time to time Pentecostal church services. Two examples are Luis and Fabian. While their mothers were active evangelicals, the official religion of Luis and Fabian was Catholicism. Both of them sometimes went to Catholic and evangelical church services but did not practice evangelical Protestantism or Catholicism on a regular basis. Despite the fact that these interviewees were not dedicated to a regular religious practice in their childhood, they had established some type of relationship to Pentecostalism and were familiar with the movement and its belief system. Later in life, in the face of personal hardships they became active members of a Pentecostal church. Luis, for instance, was reluctant to become an active member of the Pentecostal movement until he experienced a deep depression. In the context of the depression he started to visit his mother's church on a regular basis. He experienced an improvement in his well-being and finally became an active member of the church. Again, having social bonds with a Pentecostal and suffering a personal crisis appear to be central factors for converting to the movement.

\subsubsection{Middle Class Pentecostals with "Orthodox" Catholic Backgrounds}

A different style of practicing Catholicism is defined as "orthodox" Catholicism. This style is marked by regular participation in the Catholic Sunday mass. In five cases, middle class interviewees claimed to have attended Sunday mass on a regular basis during childhood.

Nadia, for instance, went each Sunday to mass. In most cases, she went alone to the Catholic Church which was located close to her parental home while her mother was more engaged in popular Catholicism and the consultation of faith healers and witches. However, Nadia's grandmother was Pentecostal. Her grandmother's religious affiliation allowed Nadia to become 
familiar with Pentecostalism. Later, Nadia and her mother together converted to Pentecostalism. ${ }^{17}$

Other middle class interviewees participated together with their parents or were obligated to attend Catholic masses regularly by their Catholic boarding school. Maria, for instance, grew up in a very Catholic household and went to mass every Sunday. At the same time, her parents were also engaged in popular Catholicism. Later in her life, her husband started to visit a Pentecostal church due to a crisis. His business had burned down and he sought relief in a Pentecostal congregation to which some of his relatives belonged. After his conversion, Maria joined her husband and started participating in the congregation. Yet, in the beginning she was not convinced and remained Catholic. Only after several years of engagement did she experience a conversion in an evangelical mass event and became a Pentecostal.

In other cases, contact with evangelical Protestantism already existed during childhood. Camila and Isabela practiced orthodox Catholicism during their childhood, while their mothers were active Pentecostals and took them to Pentecostal church services. Camila and Isabela disaffiliated later in their lives - after childhood - from the Catholic Church and began regular Pentecostal practice.

\subsection{Explaining Middle Class Conversions to Pentecostalism}

Informants converted at different stages in their lives to Pentecostalism: some relatively early under the influence of their family, others at a later time in their life. ${ }^{18}$

In the majority of cases, the conversion to Pentecostalism was motivated by a problem and facilitated by contact with Pentecostalism. ${ }^{19}$ Most informants suffered from problems such as loneliness, depression, health issues and family strife. Facing these problems, they visited a Pentecostal church in search for relief. In addition, interviewees generally had contact with a person who facilitated their contact with the movement during the crisis. This person was in most cases a relative, partner, or a close friend.

\footnotetext{
17 Interview Nadia.

18 After converting and participating for a time in a congregation, most informants switched to other churches and arrived at one point in their lives at their current church. The number of religious switches varies among my informants: some were affiliated with just one different church; others had tried several religious options before joining their current church.

See also Gooren 2010; Rambo 1993.
} 
Hence, social contacts with the movement as well as the experience of a crisis facilitated the conversion of middle class interviewees. Both factors have already been explored by other studies and are generally regarded as crucial factors for the conversion to Pentecostalism among the lower class. ${ }^{20}$ However, an additional ingredient appears to be important for explaining the conversion of middle class actors: early contact with popular religion. While this ingredient is usually assumed to be given in the lower class, its presence is more problematic in the educated middle class. Interestingly, the vast majority of middle class interviewees had experienced early contact with popular religion in the form of popular Catholicism or Pentecostalism. This is evident in the cases of those who were raised in evangelical Protestantism and popular Catholicism, but less evident for those who were raised as nominal or "orthodox" Catholics. However, even among nominal and "orthodox" Catholics the majority of middle class interviewees had experienced early contact with some type of popular religion, in most cases Pentecostalism. Hence, the vast majority of middle class interviewees have become familiar with the concepts and worldview of popular religion during their upbringing. ${ }^{21}$ Being familiar with popular religion, they have a predisposition for religious options that include elements of popular religion.

Besides their contact with popular religion, middle class interviewees were also socialized in the context of the porteño middle class: visiting universities, living and working in close contact with (non-Pentecostal) class peers, they are familiar with the representations of the middle class to which they adapt their behavior and judgments. Thus, they are situated in an ambivalent position between popular religion and the representations of the educated middle class which aspires to be decent, secular, rational, and sober.

The presence of popular religion among middle class interviewees may be traced back to what Bourdieu calls the hysteresis effect. Bourdieu's concept of the hysteresis effect supposes that unadapted behavior is the product of a mismatch between the habitus - which developed in adaptation to a specific context - and a new social environment. Due to its inertia, the habitus does not immediately adapt to new social environments. The mismatch between the habitus and a new context leads to a discordance between the practice generated by the habitus and the requirements of the new social environment:

20 See, for instance, Algranti 2010: 151-152; Míguez 1998: 51-52; Smilde 2005; 2007.

21 The affinity for popular religion appears to be a product of primary socialization. Thus, Semán $(1997: 135 ; 2000)$ points out that the religious worldview and practices of popular religion are generally imparted by primary socialization within the context of the family. Popular religiosity is (re)produced and spreads within in the bonds of social networks. 
the practice appears inappropriate. ${ }^{22}$ For the case of middle class Pentecostals the concept of the hysteresis effect would assume that middle class Pentecostals experienced upward social mobility and that their religious habitus has not yet adapted to the new class position and its representations. Having been shaped by the cultural and religious universe of the lower class, their habitus has maintained its predispositions for popular religion and has not yet developed more "appropriate" religious predispositions. That said, the hysteresis effect can explain the interview cases that experienced upward social mobility from the lower to the middle class. However, explaining interview cases that had already grown up in the middle class is more difficult with this approach. An explanation based on the hysteresis effect infers that maintaining middle class status in the long run leads to the disappearance of popular religion and the incorporation of an appropriate middle class habitus. However, with regard to the sample this seems not to be the case. Those who grew up in the middle class - the majority of the interviewees - also grew up in contact with popular religiosity. ${ }^{23}$

A more compelling explanation can be drawn from Lahire's concept of multiple socializations and Schäfer's concept of the habitus as a complex network of dispositions. ${ }^{24}$ According to these approaches, actors are socialized in a variety of social environments which often imply different and sometimes even conflicting cultural standards and affinities. Participating in a variety of social environments in the course of their socialization, actors develop different and sometimes even conflicting dispositions.

This approach can be applied to the case of middle class Pentecostalism: despite having been raised in the context of the middle class and its

22 Bourdieu 1979: 122-126, 157-159; 1987b: 111, 116-118. For a critique of the hysteresis concept see King 2000: 427-428.

23 Particularly regarding the group with evangelical backgrounds an explanation based on the hysteresis effect appears to be misleading. The majority of the interviewees in this group are from middle class backgrounds. Many of them have a long-standing evangelical family and middle class history. According to the hysteresis effect one would expect that second generation middle class families would finally adapt to the middle class representations and withdraw from their "unadapted" practices and beliefs of Pentecostalism. This does not seem to be the case, however.

24 Lahire $(2003 ; 2004 / 2006$; 2010) explains the deviations of actors from their class representations by referring to the presence of multiple socialization channels. In modern, plural societies individuals are subject to various socializations which lead individuals to assume contradicting values and concepts. Schäfer $(2005,2015)$ describes the habitus as a complex network of dispositions. This network is in many cases rather loosely integrated and may comprise dispositions that contradict each other. 
representations, middle class interviewees were also socialized in the "lower class" context of popular religion in which they developed "inappropriate" religious predispositions. ${ }^{25}$ These "inappropriate" predispositions become mobilized by the simultaneous presence of two conditions: the experience of a life crisis and contact with a Pentecostal. Facing a life crisis and being persuaded by a Pentecostal peer, middle class actors are more likely to comply with their inappropriate religious predispositions. ${ }^{26}$

Due to its representations, the educated middle class tends to regard popular religion and Pentecostalism critically. The critical attitude towards Pentecostalism increases the threshold for converting to the movement. Two elements that appear to decrease the threshold - aside from early contact with popular religion - are close social contacts to members of the Pentecostal movement and the suffering of a crisis. If these elements - early contact to popular religion, social contacts in the Pentecostal movement and the experience of a crisis - come together, middle class individuals are more susceptible to convert to Pentecostalism.

25 Another potential explanation of deviating tendencies can be facilitated by McPherson's (2004) concept of niche overlap. McPherson proposes the concept of the Blau space. The Blau space is a social space which consists of different social niches. He states with regard to the niche overlap: "Blau space explains the fact that a single individual may often hold conflicting attitudes: individuals in the overlap of two 'logically inconsistent' attitudes are likely to possess both attitudes" (McPherson 2004: 277). According to the concept of niche overlap, socialization in different cultural universes is due to the overlap of different social niches in the life of the individual: the individual participates in different social niches and incorporates different - partly contradicting - social concepts and expectations. Interviewees were raised in different social niches: in the middle class niche and the niche of popular religion. Both niches embrace different and in part mutually exclusive concepts and discourses. The socialization in different social niches led middle class informants to develop an affinity for popular religion but also to adapt to the representations of the educated middle class.

26 The development of predispositions for popular religion may not be a rare exception in the Argentinean middle class. Popular religion may be more prevalent than the conception of the middle class suggests. Particularly regarding the popularity of New Age and Charismatic Catholicism - which also include aspects of popular religion such as the holistic worldview - it can be argued that socialization in popular religion is not an exception in the middle class. The presence of these groups in the middle class illustrates that some members of the middle class resist the pressure to be secular and "sober". As Viotti (2011) points out, there seems to be a rejection of the ideal of rationality and secularity. The presence of popular religion in the middle class points to a potential dissonance between the representations of the educated middle class and its actual religious 


\subsection{Summary}

Analyzing the tensions that middle class Pentecostals experience due to their religious affiliation raises the question of how they come to choose a religious option that will probably be perceived by their middle class environment as inappropriate. This question was tackled in this chapter by analyzing the data from qualitative interviews with Pentecostals. The analysis reveals that the interaction of three factors in the life of the middle class interviewees has in many cases facilitated their conversion to Pentecostalism: (1) early contact with popular religion, often in the form of Pentecostalism, (2) a life crisis, and (3) a contact to a Pentecostal member during this life crisis. The early contact with popular religion seems to have shaped the religious predispositions of these actors. They are sensitized for popular religions. Facing a crisis and coming through a Pentecostal acquaintance - again into contact with popular religion in the form of Pentecostalism, they are more likely to grasp and appreciate the religious concepts behind this practice than other middle class actors. Hence, the interaction between a religious predisposition and a conducive context consisting of a life crisis and the contact to a Pentecostal acquaintance appears to facilitate middle class conversions to Pentecostalism.

However, when converting to Pentecostalism, middle class actors may experience the inappropriateness of their religious practice in the form of tensions and frictions. In order to deal with these tensions they have to develop strategies. ${ }^{27} \mathrm{~A}$ strategy for negotiating the (in)appropriatenessof their religious practice is boundary work, as will be seen in the following chapters.

beliefs and practices. Nevertheless, conclusions about the prevalence of popular religion among the educated middle class have to be drawn carefully since it is difficult to estimate its impact in this segment of the population.

The middle class may develop strategies towards the public and political sphere to gain symbolic capital and improve the social position of the movement thereby lowering the tension. These macro strategies have already been described by Wynarzcyk (2009a; 2009b; 2010). This study stresses, instead, the meso and micro level forms of coping with the ill fit: on these levels, I emphasize religious taste and style. Both allow for establishing symbolic boundaries with regard to the lower class image of the movement. 